\title{
Ectomycorrhizal fungal communities on seedlings and conspecific trees of Pinus mugo grown on the coastal dunes of the Curonian Spit in Lithuania
}

\author{
Algis Aučina • Maria Rudawska • Tomasz Leski • \\ Darius Ryliškis • Marcin Pietras • Edvardas Riepšas
}

Received: 30 June 2010 / Accepted: 30 September 2010 /Published online: 12 October 2010

(C) The Author(s) 2010. This article is published with open access at Springerlink.com

\begin{abstract}
Ectomycorrhizal (ECM) communities of mature trees and regenerating seedlings of a non-native tree species Pinus mugo grown in a harsh environment of the coastal region of the Curonian Spit National Park in Lithuania were assessed. We established three study sites (S1, S2, and S3) that were separated from each other by $15 \mathrm{~km}$. The ECM species richness was rather low in particular for mature, 100-year-old trees: 12 ectomycorrhizal taxa were identified by molecular analysis from 11 distinguished morphotypes. All 12 taxa were present on seedlings and on mature trees, with between 8-11 and 9-11 taxa present on seedlings and mature trees, respectively. Cenococcum geophilum dominated all ECM communities, but the relative abundance of C. geophilum mycorrhizas was nearly two times higher on seedlings than on mature trees. Mycorrhizal associations formed by Wilcoxina sp., Lactarius rufus, and Russula paludosa were also abundant. Several fungal taxa were only occasionally detected, including Cortinarius sp.,
\end{abstract}

\footnotetext{
A. Aučina $\cdot$ D. Ryliškis

Botanical Garden of Vilnius University,

43 Kairènų Str,

10239 Vilnius-40, Lithuania

M. Rudawska $(\bowtie) \cdot$ T. Leski $\cdot$ M. Pietras

Institute of Dendrology, Polish Academy of Sciences,

5 Parkowa Str.,

62-035 Kórnik, Poland

e-mail: mariarud@man.poznan.pl

E. Riepšas

Department of Sylviculture, Lithuanian University of Agriculture,

11 Studentų Str,

Akademija 53361 Kaunas district, Lithuania

e-mail: mi@nora.lzuu.lt
}

Cortinarius obtusus, Cortinarius croceus, and Meliniomyces sp. Shannon's diversity indices for the ECM assemblages of P. mugo ranged from 0.98 to 1.09 for seedling and from 1.05 to 1.31 for mature trees. According to analysis of similarity, the mycorrhizal communities were similar between the sites $(R=0.085 ; P=0.06)$ and only slightly separated between seedlings and mature trees $(R=0.24 ; P<$ $0.0001)$. An incidental fruiting body survey that was conducted weakly reflected the below-ground assessment of the ECM fungal community and once again showed that ECM and fruiting body studies commonly supply different partial accounts of the true ECM fungal diversity. Our results show that $P$. mugo has moved into quite distinct habitats and is able to adapt a suite of ECM symbionts that sufficiently support growth and development of this tree and allow for natural seedling regeneration.

Keywords Mountain pine - Cenococcum geophilum . Ectomycorrhizal fungi

\section{Introduction}

Mountain pine (Pinus mugo subsp. mugo Turra) is a highaltitude European pine that grows naturally in the subalpine regions of central and southeast Europe but also occurs at lower altitudes in peat bogs and frost hollows (Christensen 1987; Richardson 1998). With respect to water and soil properties, $P$. mugo is considered to be a pioneer species, colonizing areas that are inaccessible to other woody plants (Piękoś-Mirkowa and Mirek 1996). Since the mid-1800s, mountain pine was introduced with success in Denmark, Norway, Finland, Sweden, Estonia, Lithuania, and other countries and revealed great ability to adapt to adverse soil 
conditions (e.g., dry sandy sites, alkaline, and acid substrata) and has naturalized in scattered places (Fremstad and Elven 1997; Jonsell 2000; Lid and Lid 2005; Øyen 1999). Vigorous growth and successful adaptation in harsh conditions has resulted in the wide use of mountain pine to protect against soil erosion, in particular to stabilize sandy soils along coastlines (Cinovskis et al. 1993; Øyen 1999).

On the Curonian Spit in Lithuania, the first plantations of $P$. mugo were established on the coastal sand dunes nearly 200 years ago (Strakauskaite 2004), based on seedlings produced in Denmark (most importantly Jutland; Riepšas, personal communication), and at present, mountain pine plantations are well established. Naturally regenerating seedlings of $P$. mugo appear near mature trees, demonstrating the adaptability of the mountain pine to coastal sand dune conditions.

As with most tree species in boreal and temperate forests, $P$. mugo lives in symbiosis with ectomycorrhizal (ECM) fungi. Ectomycorrhizas are exceptionally important at sites with extremely poor, nutrient-limiting soils, such as coastal dunes, where these associations especially facilitate nutrient and water availability (Smith and Read 1997).

Data concerning the mycorrhizal status of $P$. mugo have been reported in only a few studies and are restricted to the natural range of subalpine belt (Dominik and Nespiak 1953; Dominik et al. 1954). All of these studies were conducted decades ago and are constrained by the obvious methodological limits of those times. Only three mountain pine mycorrhizas (Rhizopogon melanogastroides, Russula firmula, and Dermocybe palustris) received detailed morphological and anatomical description (Raidl et al. 1998; Treu 1990; Uhl and Agerer 1987). Fruiting body sampling and identification recorded various ECM fungal symbionts associated with P. mugo such as Amanita, Boletus, Cenococcum, Chroogomphus, Cratherellus, Cortinarius, Hygrophorus, Inocybe, Laccaria, Lactarius, Rhizopogon, Russula, Scleroderma, Suillus, Tricholoma, and Xerocomus (Ronikier 2009; Trappe 1962). Recently, morphotyping of ectomycorrhizas on the fine roots of young $P$. mugo trees grown in the Swiss Alps revealed that Suillus granulatus was the dominant fungus found by morphotyping and as a fruit body (Wiemken and Boller 2006). The below-ground ectomycorrhizal fungal communities of $P$. mugo have not been detailed described in either the native subalpine habitat or in the coastal dunes. Ectomycorrhizal fungal communities associated with Pinus contorta, Pinus muricata, and Pinus thunbergii grown in coastal forests have been lately documented (Ashkannejhad and Horton 2006; Matsuda et al. 2009; Obase et al. 2009; Peay et al. 2007) and indicate that coastal pine systems develop ECM fungal associations composed of common generalists, often with the dominance of Cenococcum geophilum. However, there is uncertainty as to how universal this pattern of ECM fungal associations is in other coastal pine systems. To our knowledge, this is the first study presenting the ECM community structure of mature mountain pines and naturally regenerating seedlings growing in the coastal pine forests of the Curonian Spit National Park. The results obtained from this study will provide background information on the ecological role of EM fungi associated with $P$. mugo in harsh environmental conditions (drought, salinity, low soil water content and $\mathrm{pH}$, poor soil nutrient content, etc.).

\section{Materials and methods}

Study sites

This study was conducted in healthy, pure mountain pine (P. mugo Turra) forests in the Lithuanian portion of the Curonian Spit where P. mugo grows as a tree of 3 to $4 \mathrm{~m}$ height. The oldest mountain pines are approximately 100 years old. The mean annual temperature in the region is $7.4^{\circ} \mathrm{C}$, and the mean annual precipitation is $771 \mathrm{~mm}$. The three study sites were located in a large $P$. mugo forest (each up to $30 \mathrm{ha}$ ) and were designated as $\mathrm{S} 1\left(55^{\circ} 39^{\prime} \mathrm{N}\right.$, $\left.21^{\circ} 07^{\prime} \mathrm{E}\right), \mathrm{S} 2\left(55^{\circ} 25^{\prime} \mathrm{N}, 21^{\circ} 05^{\prime} \mathrm{E}\right)$, and S3 $\left(55^{\circ} 22^{\prime} \mathrm{N}, 21^{\circ}\right.$ $03^{\prime}$ E). At each study sites, one plot $(6 \times 80 \mathrm{~m})$ was established for seedlings and soil cores samplings. The distance between each study site was about $15 \mathrm{~km}$. Study sites are surrounded by Pinetum vacciniosum forest type. Mountain pine stands were developed on sandy, haplic podzol soils (FAO 2006) with a thin humus layer (3.1 \pm $0.6 \mathrm{~cm}$ ) and a $28-38-\mathrm{cm}$ clear eluvial horizon. The ground vegetation was dominated by Vaccinium vitis-idaea $\mathrm{L}$., mosses and lichens (Polytrichum piliferum Hedw., Polytrichum juniperinum Hedw., Dicranum polysetum Michx., Pleurozium schreberi (Brid.) Mitt., Cladonia rangiferina (L.) Web., and Cladonia sylvatica (L.) Hoffm.).

\section{Chemical analysis of soils}

The soil carbon content and the nutrient composition were determined for each study site using four soil cores taken adjacent to sites where individual soil cores had been sampled for ECM fungi. Following field collection, soil was immediately air-dried and passed through a 2-mm mesh screen and submitted to analysis. Chemical analysis was performed using the elemental combustion system CHNS-O and atomic absorption spectroscopy (Varian 220 FS). A complete description of the soil analysis is presented in our earlier paper (Aučina et al. 2007). The $\mathrm{pH}$ of the soil was determined in de-ionized water with a $\mathrm{pH}$-meter equipped with a glass electrode. Soil water content $(w / w)$ was estimated from four soil samples per site, which were dried at $100 \pm 5^{\circ} \mathrm{C}$ for 1 week. 
Sampling of seedlings and fine roots of mature trees

At each study site, 12 randomly selected 2- to 3-year-old naturally regenerating seedlings were harvested, along with 20 soil samples containing the roots of mature $P$. mugo trees. Sampling was conducted in September 2007. Seedlings were excavated from under the canopy of mature trees with their surrounding soil. The soil cores were obtained using a soil corer $(10 \mathrm{~cm}$ diameter) and were taken from a depth of $0-20 \mathrm{~cm}$ after the removal of the litter layer. The harvested seedlings and soil cores were immediately wrapped and placed into labeled plastic bags and transferred to the laboratory at the Vilnius University Botanical Garden. All samples were stored at $-20^{\circ} \mathrm{C}$ until a further analysis. In total, 36 pine seedlings and 60 soil cores were sampled. The occasionally occurring fruiting bodies from all study sites were collected and identified at the time seedling and soil sampling to complement the picture of the ECM fungal species composition.

\section{Mycorrhizal evaluation}

The root systems of seedlings and roots from the soil samples were extracted from the soil using a sieve under tap water and cut into 5-cm fragments. For each seedling or soil sample, three subsamples were counted until approximately 250 root tips. Observations of the ectomycorrhizas were conducted under a dissecting microscope at $\times 10$ to $\times 60$ magnification. The ECM morphotypes were described based on macroscopic observations (ramification system; color, shape, texture, and thickness of the mantle; presence and organization of the emanating hyphae; rhizomorphs; and other elements) and were compared to a database from the Laboratory of Mycorrhizal Research at the Institute of Dendrology (Aučina et al. 2007; Leski et al. 2010; Rudawska et al. 2006). The relative abundance of each morphotype (number of root tips of each morphotype/total number of mycorrhizas) was calculated for each subsample.

The selected samples of morphotypes were stored in $2 \%$ cetyltrimethylammonium bromide buffer for further analysis. We made no attempt to relate morphotypes between samples until molecular analysis was complete; thus, each morphotype sample was treated separately in a subsequent molecular typing and pooled for abundance calculation only after the molecular analysis indicated that morphotypes are identical. Complete methods for the molecular identification of mycorrhizas are presented in our earlier study (Aučina et al. 2007). Fungal symbionts were identified using polymerase chain reaction (PCR) amplification of the internal transcribed spacer (ITS) with the ITS1F and ITS-4 primers (White et al. 1990) and combination of RFLP and sequencing. Four single ectomycorrhizal root tips from each morphotype (from each seedling and from each soil sample) were separately subjected to RFLP analysis. Finally, two to four samples of each unique RFLP pattern from seedlings/soil samples from each site were sequenced. In total, 132 sequences were obtained. Sequencing of the PCR product was performed with a CEQ 20000XL automatic sequencer using these same set of primers. Consensus sequences were constructed, with manual editing of ambiguous readings, and were compared to published sequences in the GenBank and UNITE databases (Kõljalg et al. 2005) using the BLAST tool. Species-level identification of mycorrhizae was defined as sharing $\geq 98 \%$ of the ITS region sequence identity with the reference sequence. For mycorrhizal morphotypes that produced multiple PCR products, amplicons were cloned with the pGEM-T Easy vector system (Promega). Colonies PCR was carried out using the M13 forward and reverse primers (Promega). Clones containing an insert were sequenced using the primers ITS1 and ITS4F.

\section{Statistical analysis}

The chemical composition of soils and the mean fungal species richness were analyzed using analysis of variance (the normality assumption for the data and the homogeneity of the variance were tested through the Shapiro-Wilk test and the Leven test, respectively). Post hoc comparisons of means between sites were made using Tukey's test at a significance level of $P<0.05$. At the site level, the average species richness was compared using a $t$ test. For relative abundances, no homogeneity of variance was found, and differences in the relative abundance of morphotypes between the mountain pine sites were therefore tested using the Kruskal-Wallis and Mann-Whitney $U$ tests. Computations were performed using the statistical software package Statistica 5.5. Estimates of the true species richness (bootstrap, first-order and second-order jackknife) were calculated with the EstimateS program version 8.2.0 (Colwell 2006). Multivariate community analyses of mycorrhizal fungi were carried out with PAST 1.89 software (Hammer et al. 2001) and were based on square root-transformed data. The Bray-Curtis coefficient was used to create a dissimilarity matrix of species composition between any two samples. To visualize differences (based on the Bray-Curtis matrix) in the mycorrhizal community structure relative to the mountain pine sites, nonmetric multidimensional scaling ordination (NMDS) was used. NMDS plots were produced using PAST, which chooses the best solution of 11 trials based on least "stress" - a value representing the difference between ranks within the distance matrix and in the ordination plot. To compare the effects of site and age on differences in the relative abundance of mycorrhizal fungal taxa, two-way analysis of similarity (ANOSIM) was performed (Clarke and Green 1988). Similarity of percentages (SIMPER) was 
carried out to investigate which taxa were responsible for these differences. All absolute data were square roottransformed prior to the analysis.

\section{Results}

The soil properties of the three tested sites are summarized in Table 1. Significant differences between sites were found in the concentrations of $\mathrm{K}, \mathrm{Ca}, \mathrm{Mg}, \mathrm{C}$, and $\mathrm{C} /$ $\mathrm{N}$ ratio in the soil. Mean values of $\mathrm{N}$ total, $\mathrm{NH}_{4}{ }^{+}, \mathrm{NO}_{3}{ }^{-}$, and $\mathrm{P}$ did not differ significantly between three tested sites. The $\mathrm{pH}$ of the soils was acidic and ranged between 3.5 and 3.8, without significant differences between the sites. Soil water content from the tested sites was low and ranged between $4.7 \%$ and $6.3 \%(w / w)$, without significant differences among the sites.

The rate of mycorrhizal colonization at all three sites was very high and neared $100 \%$ for both seedlings and mature trees. From 11 morphotypes distinguished on both the regenerating seedlings and the mature trees, 12 mycorrhizal taxa were identified. The suilloid morphotypes turned out to be species mixtures of two Suillus species: Suillus bovinus and Suillus luteus (Table 2). All 12 taxa were present on seedlings and mature trees, with between 8-11 and 9-11 taxa on seedlings and mature trees, respectively, depending on the site. Mean fungal species richness ranged between $4.1-4.2$ and 3.3-4.5 per seedling and soil sample, respectively. The mean richness of the fungal taxa in soil samples containing the roots of mature $P$. mugo trees differed significantly between the sites (Table 2).

The estimated species richness values were 14.67, 13.67, and 8.92 by Jackknife $1 ; 17.24,17.00$, and 8.23 by Jackknife 2 ; and $12.55,11.42$, and 8.58 by bootstrap estimator for seedlings in sites 1,2 , and 3 , respectively. For mature trees, the estimated species richness values were 9.28, 12.90, and 10.95 (Jackknife 1); 9.31, 12.38, and 11.85 (Jackknife 2); and 9.25, 12.14, and 10.45 (bootstrap), respectively, in sites 1,2 , and 3 , respectively (Table 2).

C. geophilum dominated ECM communities on both seedlings and mature trees. The relative abundance of $C$. geophilum mycorrhizas was nearly two times higher on seedlings than on mature trees, and this difference was statistically significant. Mycorrhizas formed by Wilcoxina sp., Lactarius rufus, and Russula paludosa were also abundant. Several fungal taxa, such as Cortinarius sp., Cortinarius obtusus, Cortinarius croceus, and Meliniomyces $\mathrm{sp}$. were occasionally detected on the fine roots of the regenerating seedlings and the mature trees at all sites (Table 2). The Shannon's diversity indices for the ECM assemblages of $P$. mugo seedlings ranged from 0.98 to 1.09 and from 1.05 to 1.31 for mature trees.

According to ANOSIM, mycorrhizal communities were similar between sites $(R=0.085 ; P=0.06)$, but the ANOSIM did detect a statistically significant differences between seedlings and mature trees $(R=0.24 ; P<0.0001)$. The fact that the R-statistic was $<0.25$, however, indicated that seedling and mature tree communities are only barely separable and although statistically significant, the differences were not very strong. Consistently, the NMDS ordinations of the mycorrhizal fungal assemblages (final stress $=0.18$ ) showed incomplete and partly overlapped separation based on mountain pine age (Fig. 1). SIMPER analysis indicated that $C$. geophilum, Wilcoxina rehmii, $L$. rufus, and $R$. paludosa were the main explanatory species for the observed dissimilarity between seedlings and mature trees of P. mugo (with $14.6 \%, 9.5 \%, 8.4 \%$, and $6.6 \%$ contribution in dissimilarity).

During a one-time survey, fruiting bodies of the following ectomycorrhizal fungal taxa were found: Cortinarius тисо-
Table 1 The nutrient concentrations, $\mathrm{pH}$, and water content in soil at the three study sites (values and means $\pm \mathrm{SE} ; n=4)$

${ }^{\text {a }}$ Different letters indicate significant differences between sites (Tukey's test, $P<0.05$ )

\begin{tabular}{|c|c|c|c|}
\hline & \multicolumn{3}{|l|}{ Site } \\
\hline & $\mathrm{S} 1$ & $\mathrm{~S} 2$ & $\mathrm{~S} 3$ \\
\hline$N(\%)$ & $0.03 \pm 0.001$ & $0.03 \pm 0.004$ & $0.03 \pm 0.01$ \\
\hline $\mathrm{NH}_{4}^{+}\left(\mathrm{mg} \mathrm{kg}^{-1}\right)$ & $2.5 \pm 0.48$ & $2.8 \pm 0.21$ & $2.7 \pm 0.25$ \\
\hline $\mathrm{NO}_{3}^{-}\left(\mathrm{mg} \mathrm{kg}^{-1}\right)$ & $0.1 \pm 0.03$ & $0.6 \pm 0.27$ & $0.2 \pm 0.02$ \\
\hline $\mathrm{P}\left(\mathrm{mg} \mathrm{kg}^{-1}\right)$ & $30.7 \pm 4.41$ & $27.0 \pm 1.15$ & $38.7 \pm 3.18$ \\
\hline $\mathrm{K}\left(\mathrm{mg} \mathrm{kg}^{-1}\right)$ & $76.0 \pm 6.24 \mathrm{~b}^{\mathrm{a}}$ & $52.7 \pm 1.76 b$ & $107.7 \pm 7.26 \mathrm{a}$ \\
\hline $\mathrm{Ca}\left(\mathrm{mg} \mathrm{kg}^{-1}\right)$ & $32.0 \pm 2.52 \mathrm{ab}$ & $25.0 \pm 1.53 b$ & $40.3 \pm 2.73 a$ \\
\hline $\mathrm{Mg}\left(\mathrm{mg} \mathrm{kg}^{-1}\right)$ & $14.7 \pm 1.63 \mathrm{ab}$ & $9.6 \pm 0.50 \mathrm{~b}$ & $16.3 \pm 2.03 \mathrm{a}$ \\
\hline $\mathrm{C}(\%)$ & $2.6 \pm 0.29 b$ & $2.4 \pm 0.24 b$ & $4.6 \pm 0.61 \mathrm{a}$ \\
\hline $\mathrm{C} / \mathrm{N}$ & $75.1 \pm 8.65 b$ & $93.0 \pm 6.47 \mathrm{~b}$ & $179.7 \pm 44.91 \mathrm{a}$ \\
\hline $\mathrm{pH}_{\mathrm{H} 2 \mathrm{O}}$ & $3.8 \pm 0.19$ & $3.5 \pm 0.06$ & $3.5 \pm 0.10$ \\
\hline Soil water content, $\%(w / w)$ & $6.3 \pm 0.93$ & $4.7 \pm 0.52$ & $5.1 \pm 1.17$ \\
\hline
\end{tabular}


Table 2 Molecular identification, relative abundance, observed total and mean species richness ( $\pm \mathrm{SE}$ ) and estimated species richness of ectomycorrhizal fungi on the roots of naturally regenerating seedlings
( $n=12$ at each site) and mature trees ( $n=20$ soil samples at each site) of P. mugo grown on coastal dunes of Curonian Spit

\begin{tabular}{|c|c|c|c|c|c|c|c|c|}
\hline \multirow[t]{3}{*}{ Identification } & \multirow[t]{3}{*}{ Closest match } & \multirow{3}{*}{$\begin{array}{l}\text { Identity } \\
(\%)\end{array}$} & \multicolumn{6}{|c|}{ Relative abundance (\%) } \\
\hline & & & \multicolumn{2}{|l|}{$\mathrm{S} 1$} & \multicolumn{2}{|l|}{$\mathrm{S} 2$} & \multicolumn{2}{|l|}{ S3 } \\
\hline & & & Seedlings & $\begin{array}{l}\text { Mature } \\
\text { trees }\end{array}$ & Seedlings & $\begin{array}{l}\text { Mature } \\
\text { trees }\end{array}$ & Seedlings & $\begin{array}{l}\text { Mature } \\
\text { trees }\end{array}$ \\
\hline \multicolumn{9}{|l|}{ Ascomycota } \\
\hline $\begin{array}{l}\text { Cenococcum } \\
\text { geophilum }\end{array}$ & $\begin{array}{l}\text { Cenococcum geophilum } \\
\text { (DQ068980) }\end{array}$ & 99 & $\begin{array}{l}62.0 \pm \\
4.16 \mathrm{a}^{\mathrm{a}}\end{array}$ & $\begin{array}{l}31.0 \pm \\
2.44 \mathrm{~b}\end{array}$ & $\begin{array}{l}52.0 \pm \\
4.99 \mathrm{a}\end{array}$ & $\begin{array}{l}29.2 \pm \\
3.95 b\end{array}$ & $\begin{array}{c}56.8 \pm \\
6.56 \mathrm{a}\end{array}$ & $\begin{array}{l}34.1+ \\
3.09 \mathrm{~b}\end{array}$ \\
\hline Wilcoxina sp. & Wilcoxina rehmii (DQ069001) & 97 & $\begin{array}{c}18.8 \pm \\
2.81 \mathrm{~A}\end{array}$ & $26.7 \pm 3.89$ & $\begin{array}{c}27.8 \pm \\
3.05 \mathrm{~A}\end{array}$ & $32.8 \pm 3.88$ & $\begin{array}{l}7.7 \pm \\
2.40 \mathrm{Bb}\end{array}$ & $\begin{array}{r}29.7+ \\
3.73 \mathrm{a}\end{array}$ \\
\hline Pezizomycotina & $\begin{array}{l}\text { uncultured Pezizomycotina } \\
\text { (DQ273331) }\end{array}$ & 90 & $\begin{array}{l}2.8 \pm \\
2.08 \mathrm{AB}\end{array}$ & $3.3 \pm 1.64$ & $\begin{array}{l}0.5 \pm \\
0.47 \mathrm{~B}\end{array}$ & $5.3 \pm 2.52$ & $\begin{array}{l}15.5 \pm \\
4.66 \mathrm{~A}\end{array}$ & $5.2+3.43$ \\
\hline Meliniomyces sp. & $\begin{array}{l}\text { Meliniomyces variabilis } \\
\text { (EF093173) }\end{array}$ & 97 & $0.1 \pm 0.06$ & $0.5 \pm 0.37$ & - & $0.5 \pm 0.35$ & - & - \\
\hline \multicolumn{9}{|l|}{ Basidiomycota } \\
\hline Russula paludosa & Russula paludosa (AJ971402) & 98 & $8.9 \pm 3.21$ & $13.6 \pm 4.04$ & $8.8 \pm 1.92$ & $6.5 \pm 3.25$ & $16.0 \pm 3.00$ & $8.5+2.04$ \\
\hline Suilloid & $\begin{array}{l}\text { Suillus bovinus (L54077) } \\
\text { Suillus luteus (GU373495) }\end{array}$ & 99 & $5.5 \pm 2.56$ & $5.9 \pm 1.97$ & $4.5 \pm 1.78$ & $2.4 \pm 1.69$ & $1.1 \pm 0.72$ & $5.8+1.78$ \\
\hline Basidiomycota & $\begin{array}{l}\text { Uncultured ectomycorrhiza } \\
\text { (FJ348387) }\end{array}$ & 90 & $0.8 \pm 0.84$ & - & $0.6 \pm 0.61$ & $0.4 \pm 0.37$ & $0.4 \pm 0.45$ & - \\
\hline Lactarius rufus & Lactarius rufus (EU346873) & 99 & $0.4 \pm 0.33 \mathrm{~b}$ & $\begin{array}{c}18.3 \pm \\
4.63 \mathrm{a}\end{array}$ & $5.5 \pm 3.68$ & $21.3 \pm 5.40$ & $2.6 \pm 1.39 \mathrm{~b}$ & $\begin{array}{c}10.8+ \\
2.23 \mathrm{a}\end{array}$ \\
\hline Cortinarius sp. & Cortinarius sp. (AF430288) & 96 & $0.4 \pm 0.39$ & $0.6 \pm 0.47$ & - & $1.2 \pm 0.71$ & - & $2.5+1.38$ \\
\hline Cortinarius obtusus & $\begin{array}{l}\text { Cortinarius cf. obtusus } \\
\text { (FJ039610) }\end{array}$ & 98 & $0.3 \pm 0.29$ & - & $0.1 \pm 0.14$ & - & - & $3.1+1.43$ \\
\hline Cortinarius croceus & $\begin{array}{l}\text { Cortinarius croceus } \\
\text { (UDB000129) }\end{array}$ & 99 & - & - & $0.1 \pm 0.14$ & $0.4 \pm 0.37$ & - & $0.3+0.31$ \\
\hline \multicolumn{9}{|l|}{ Coexistent taxa } \\
\hline Unidentified & $\begin{array}{l}\text { Uncultured fungal clone } \\
\text { (EU292463) }\end{array}$ & 96 & + & & + & & + & \\
\hline Helotiales & Uncultured Helotiales (EF619698) & 98 & + & & + & & + & \\
\hline \multicolumn{3}{|c|}{ Observed species richness } & 11 & 9 & 10 & 11 & 8 & 10 \\
\hline \multicolumn{3}{|c|}{ Mean no species per seedling/soil sample } & $4.2 \pm 0.27$ & $\begin{array}{l}3.6 \pm \\
0.18 \mathrm{~B}^{\mathrm{b}}\end{array}$ & $4.1 \pm 0.34$ & $\begin{array}{l}3.3 \pm \\
0.19 \mathrm{~B}\end{array}$ & $4.2 \pm 0.24$ & $\begin{array}{l}4.5+ \\
0.20 \mathrm{~A}\end{array}$ \\
\hline \multicolumn{3}{|l|}{ Jackknife 1} & 14.67 & 9.28 & 13.67 & 12.90 & 8.92 & 10.95 \\
\hline \multicolumn{3}{|l|}{ Jackknife 2} & 17.24 & 9.31 & 17.00 & 12.38 & 8.23 & 11.85 \\
\hline \multicolumn{3}{|l|}{ Bootstrap } & 12.55 & 9.25 & 11.42 & 12.14 & 8.58 & 10.45 \\
\hline \multicolumn{3}{|c|}{ Shannon diversity index $\left(\mathrm{H}^{\prime}\right)$} & $0.98 \pm 0.08$ & $1.18 \pm 0.05$ & $1.09 \pm 0.08$ & $1.05 \pm 0.06$ & $1.01 \pm 0.08$ & $1.31 \pm 0.06$ \\
\hline
\end{tabular}

${ }^{\text {a }}$ Different letters indicate significant differences at site level (a) and between examined sites (A) at a $P$ value of $<0.05$ (Mann-Whitney $U$ test)

${ }^{\mathrm{b}}$ Different letters indicate significant differences at site level (a) and between examined sites (A) according to the $t$ test and Tukey's (HSD) test ( $P<0.05$ ), respectively

sus, Cortinarius semisanquineus, Lactarius deliciosus, L. rufus, Lactarius volemus, R. paludosa, S. bovinus, S. luteus, Suillus variegatus, Tricholoma sp., and Xerocomus rubellus.

\section{Discussion}

To the best of our knowledge, this is the first study of the below-ground ECM community of mountain pine $(P$. mugo) growing in coastal conditions. Though not native to the environments of the north-European coastal dunes, mountain pine is important in this habitat because it is used to stabilize sandy soils against erosion and to protect human settlements along coastlines. P. mugo does not spread extensively throughout the Curonian Spit in Lithuania, occurring only in locations where it was deliberately planted (Jørgensen 2006). At the three study sites, we distinguished 12 ECM fungal taxa based on morphotyping 


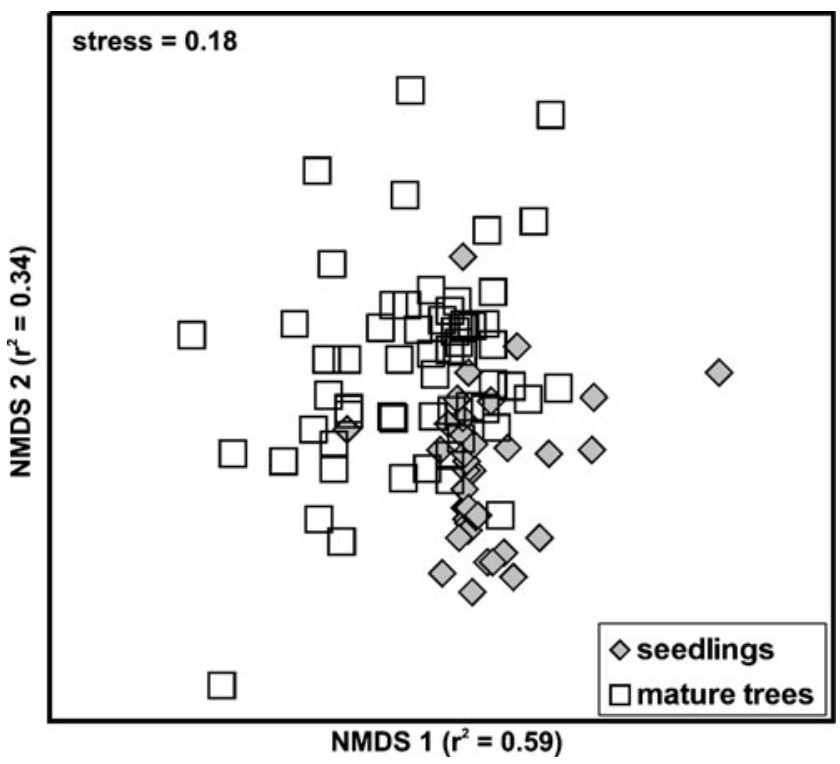

Fig. 1 Nonmetric multidimensional scaling ordination of ECM fungal communities of naturally regenerating seedlings and mature trees of $P$. mugo grown on coastal dunes of Curonian Spit

of 41,940 mature root tips and 25,164 seedlings root tips. A total of 132 mycorrhizas were sequenced. From a quantitative point of view, the below-ground ECM species richness (number of species) of tested pines was rather low. This was in accordance with our expectations to find few highly dominated fungal taxa that were well adapted to this nutrient-poor and dry habitat. This is also in accordance with investigations on the ECM status of $P$. contorta seedlings from the isolated areas of the Oregon coastal dunes where ten RFLP types were found (Ashkannejhad and Horton 2006). Recently, Matsuda et al. (2009) identified 13 species (phylotypes) of ECM fungi on naturally regenerated $P$. thunbergii seedlings from coastal dune plantations in Japan. Higher species richness (27 ECM taxa) was found on mature trees and regenerating seedlings varying in age in coastal $P$. thunbergii forests on the east coast of Korea (Obase et al. 2009). However, the number of fungal taxa observed in seedlings aged 1-3 years amounted to 14 and was only slightly higher than our results for seedlings in this same age class. Based on our sampling effort, the estimated numbers of species reached a maximal value 17.2 (Jackknife 2 at site 1) and 12.9 (Jackknife 1 at site 2) for seedlings and mature trees, respectively. These values indicate that our estimated sampling completeness (percent of observed species) reached $69.6 \%$ for seedlings and $93 \%$ for mature trees. Such results may suggest that more rare species would be discovered, especially on seedlings. Similar sampling completeness was noted in many other studies (cf. Dickie 2007). Lower estimated species richness on mature trees than on seedlings derive most likely from our sampling strategy where the whole root systems of seedlings were taken to analysis, but only tiny portion of the root system has been sampled in the soil cores taken under the mature trees. As a consequence, several ECM fungi with very low abundance could not be found on mature trees influencing the scores of species richness estimators. A low diversity of ECM communities of tested $P$. mugo in terms of species richness was also confirmed by low values of the Shannon diversity index $\left(\mathrm{H}^{\prime}\right)$. Similar results are characteristic for studies conducted in widely defined harsh environmental conditions (e.g., de Román and de Miguel 2005; Peter et al. $2008)$ and remain in contrast to the higher diversity $\left(\mathrm{H}^{\prime}\right)$ noted on undisturbed, natural sites (Korkama et al. 2006; Kranabetter et al. 2009; Walker et al. 2005).

Several explanations could account for the low observed ECM species diversity. The homogenous structure of plant cover and soil, characteristic for this study, do not create varied forest microsites that stimulate fungal diversity (Tedersoo et al. 2008). Remarkably, a clear pattern in the relationship between the number of host species and the richness of ECM fungi was presented by Dickie (2007). Low water potential in the soil on the coastal dunes may be also an important factor structuring the ECM community. The final outcome of ECM symbiosis on trees grown in low water retention is probably a result of host response but may also be caused by fungal water limitation (Kennedy and Peay 2007; Parlade et al. 2001; Querejeta et al. 2003). Under very low soil moisture conditions (i.e., strong drought), the growth of some fungi may be significantly limited (e.g., Rhizopogon; Kennedy and Peay 2007), and some fungi may not be active (Shi et al. 2002). Finally, the factor that may account for the relatively low ECM diversity recorded in our study is the non-native origin of P. mugo to the Curonian Spit. Coniferous genera such as Larix, Abies, and Picea, which have been introduced relatively recently to Britain, were each found to be associated with fewer fungal taxa than would be expected from their distributional areas (Newton and Haigh 1998). The low species diversity of our studies does not seem to be related with size of the stand, as suggested by Peay et al. (2007), because our study sites were not isolated islands but rather were established inside of the large $P$. mugo coastal forests.

At the species level, the ECM taxa of P. mugo from coastal habitat bear a resemblance to other ECM communities in coniferous forests of costal or inland dunes; all are rich in mycorrhizas of the genera Cenococcum, Wilcoxina, Lactarius, Russula, Cortinarius and of suilloid fungi (Matsuda et al. 2009; Obase et al. 2009; Smit et al. 2003). All of the recorded ECM species belonged to the multi-site (generalist) fungi and are well adapted to a wide range of community types. It is highly probable that generalist species of coniferous trees are less sensitive to the harsh 
conditions of the dune environment than specialist species. The most conspicuous specificity of our results is the very high frequency and abundance of $C$. geophilum mycorrhizas on both seedlings and mature trees. Generally, a strong dominance of $C$. geophilum ECMs is reported in stressed forest stands, which is consistent with the condition of the coastal dune forest studied here (e.g., Matsuda et al. 2009; Di Pietro et al. 2007; Obase et al. 2009). Probably due to the high fluctuations in moisture and temperature, the upper organic horizons were dominated by $C$. geophilum, which is known to be able to tolerate water and thermal stresses (Ashkannejhad and Horton 2006; Di Pietro et al. 2007; Matsuda et al. 2009; Obase et al. 2009; Scattolin et al. 2008). The higher abundance of $C$. geophilum on roots of seedlings compared to mature trees is probably attributed to the vital role which plays this fungal symbiont in regeneration and maintenance of $P$. mugo seedlings in conditions of drought stress typical for coastal dunes (Obase et al. 2009; Taniguchi et al. 2007; Kataoka et al. 2008).

The R-statistic from the ANOSIM indicated that seedlings and mature trees had nearly similar communities of mycorrhizal fungi. This result was not surprising - in our study, seedlings and mature trees (altogether in all three sites) shared this same suite of mycorrhizal fungi and differed only in the abundance of particular fungal species (mostly C. geophilum, $W$. rehmii, L. rufus, and $R$. paludosa). Such results suggest that seedlings of $P$. mugo were fully incorporated into the mycorrhizal network maintained by understory trees that play the role of "nurse trees", facilitating seedling establishment, especially in harsh condition (low nitrogen and water content in the soil) present on coastal dunes. Common mycorrhizal network is widespread and may connect not only young and mature plants (Jonsson et al. 1999; Matsuda and Hijii 2004; Obase et al. 2009) but also different tree species (Cullings et al. 2000; Horton and Bruns 1998) or trees and understory plants (Horton et al. 1999; Kennedy et al. 2003).

Our incidental fruiting body survey only weakly reflected below-ground assessment of the ECM fungal community and once again showed that ECM and fruiting body studies commonly supply different partial accounts of the true ECM fungal diversity. A similar discrepancy between fruiting body occurrence and the occurrence of appropriate ectomycorrhizas has been observed in many earlier studies (e.g., Cullings and Makhija 2001; Gardes and Bruns 1996; Nieto and Carbone 2009).

Because the characterization of the below-ground ECM fungal community of mountain pine in their native environment is lacking, we do not know if the diversity of ECM fungi found in our studies is representative for P. mugo grown in the subalpine habitat. The results of mycocoeno- logical observations conducted during four vegetative seasons show that Pinetum mugo carpaticum is rich in rare ECM fungi, despite the absence of species exclusively associated with dwarf-mountain pine (Ronikier 2009). Sixteen fungi producing epigeous fruiting bodies were classified as mycorrhizal in these studies (Cortinarius odorifer, Cortinarius percomis, Cortinarius dionysae, Cortinarius infractus, Laccaria laccata, Lactarius badiosanguineus, Lactarius aurantiacus, Lactarius deterrimus, Inocybe terrigena, Inocybe nitidiuscula, Inocybe rimosa, Craherellus tubaeformis, Chroogomphus rutilus, Hygrophorus olivaceoalbus, Russula chloroides, and Russula aff. silvestris), and none of them was found in our below- and aboveground observations. These results show that favorable habitat had an important impact in structuring the ECM community in the tested pine trees. Despite some limitations in our present study (single sampling limited to one season), our results indicate that $P$. mugo moved into a quite distinct habitat is able to adapt a suite of ECM symbionts that sufficiently support growth and development of this tree and allow for natural seedlings regeneration.

Open Access This article is distributed under the terms of the Creative Commons Attribution Noncommercial License which permits any noncommercial use, distribution, and reproduction in any medium, provided the original author(s) and source are credited.

\section{References}

Ashkannejhad S, Horton TR (2006) Ectomycorrhizal ecology under primary succession on coastal sand dunes: interactions involving Pinus contorta, suilloid fungi and deer. New Phytol 169:345354

Aučina A, Rudawska M, Leski T, Skridaila A, Riepšas E, Iwański M (2007) Growth and mycorrhizal community structure of Pinus sylvestris seedlings following the addition of forest litter. Appl Environ Microbiol 73:4867-4873

Christensen KI (1987) Taxonomic revision of the Pinus mugo complex and $P . \times$ rhaetica $(P$. mugo $\times$ sylvestris $)$ (Pinaceae). Nord J Bot 7:383-408

Cinovskis R, Laasimer L, Čibiras L (1993) Gymnospermae. In: Laasimer L, Kuusk V, Tabaka L, Lekavičius A (eds) Flora of the Baltic countries. Compendium of vascular plants, vol 1. Estonian Agricultural University Press, Tartu

Clarke KR, Green RH (1988) Statistical design and analysis for a 'biological effects' study. Mar Ecol Prog Ser 46:213-226

Colwell RK (2006) EstimateS: statistical estimation of species richness and shared species from samples. Version 8.0 user's guide and application persistent. http://purl.oclc.org/estimates

Cullings K, Makhija S (2001) Ectomycorrhizal fungal associates of Pinus contorta in soils associated with a hot spring in Norris Geyser Basin, Yellowstone National Park, Wyoming. Appl Environ Microbiol 67:5538-5543

Cullings KW, Vogler DR, Parker VT, Finley SK (2000) Ectomycorrhizal specificity patterns in a mixed Pinus contorta/Picea engelmannii forest in Yellowstone National Park. Appl Environ Microbiol 66:4988-4991 
de Román M, de Miguel AM (2005) Post-fire, seasonal and annual dynamics of the ectomycorrhizal community in a Quercus ilex L. forest over a 3-year period. Mycorrhiza 15:471-482

Dickie IA (2007) Host preference, niches and fungal diversity. New Phytol 174:230-233

Di Pietro M, Churin J-L, Garbaye J (2007) Differential ability of ectomycorrhizas to survive drying. Mycorrhiza 17:547-550

Dominik T, Nespiak A (1953) Badanie mykotrofizmu zespolów roslinnych krainy kosodrzewu w granitowych Tatrach. Acta Soc Bot Pol 22:753-769, in Polish

Dominik T, Nespiak A, Pachlewski R (1954) Badanie mykotrofizmu zespolów roslinnych regla górnego w Tatrach. Acta Soc Bot Pol 23:487-504, in Polish

FAO (2006) World reference base for soil resources 2006-a framework for international classification. World Soil Resources Reports 103. FAO, Rome

Fremstad E, Elven R (1997) Alien plants in Norway and dynamics in the flora: a review. Norsk Geogr Tidsskr 51:199-218

Gardes M, Bruns TD (1996) Community structure of ectomycorrhizal fungi in a Pinus muricata forest: above- and below-ground views. Can J Bot 74:1572-1583

Hammer O, Harper DAT, Ryan PD (2001) PAST: palaeontological statistics software package for education and data analysis. Palaeont Electron 4(1):9

Horton TR, Bruns TD (1998) Multiple-host fungi are the most frequent and abundant ectomycorrhizal types in a mixed stand of Douglas-fir (Pseudotsuga menziesii D. Don) and bishop pine (Pinus muricata. D. Don). New Phytol 139:331-339

Horton TR, Bruns TD, Parker VT (1999) Mycorrhizal fungi associated with Arctostaphylos facilitate the establishment of Pseudotsuga menziesii during succession. Can J Bot 77:93-102

Jonsell B (ed) (2000) Flora Nordica 1. Stockholm. p 368

Jonsson L, Dahlberg A, Nilsson MC, Kårén O, Zackrisson O (1999) Continuity of ectomycorrhizal fungi in self-regenerating boreal Pinus sylvestris forests studied by comparing mycobiont diversity on seedlings and mature trees. New Phytol 142:151-162

Jørgensen H (2006) NOBANIS - Invasive Alien Species Fact SheetPinus mugo. Online Database of the North European and Baltic Network on Invasive Alien Species - NOBANIS. www.nobanis.org

Kataoka R, Taniguchi T, Ooshima H, Futai K (2008) Comparison of the bacterial communities established on the mycorrhizae formed on Pinus thunbergii root tips by eight species of fungi. Plant Soil 304:267-275

Kennedy PG, Peay KG (2007) Different soil moisture conditions change the outcome of the ectomycorrhizal symbiosis between Rhizopogon species and Pinus muricata. Plant Soil 291:155165

Kennedy PG, Izzo AD, Bruns TD (2003) There is high potential for the formation of common mycorrhizal networks between understory and canopy trees in a mixed evergreen forest. J Ecol 91:10711080

Korkama T, Pakkanen A, Pennanen (2006) Ectomycorrhizal community structure varies among Norway spruce (Picea abies) clones. New Phytol 171:815-824

Kõljalg U, Larsson KH, Abarenkov K, Nilsson RH, Alexander IJ, Eberhardt U, Erland S, Hoiland K, Kjøller R, Larsson E, Pennanen T, Sen R, Taylor AF, Tedersoo L, Vrålstad T (2005) UNITE: a database providing web-based methods for the molecular identification of ectomycorrhizal fungi. New Phytol 166:1063-1068

Kranabetter JM, Durall DM, MacKenzie WH (2009) Diversity and species distribution of ectomycorrhizal fungi along productivity gradients of a southern boreal forest. Mycorrhiza 19:99-111

Leski T, Aučina A, Skridaila A, Pietras M, Riepšas E, Rudawska M (2010) Ectomycorrhizal community structure of different genotypes of Scots pine under forest nursery conditions. Mycorrhiza 20:473-481. doi:10.1007/s00572-010-0298-2
Lid J, Lid DT (2005) Norsk flora. 7. utg. In: Elven R (ed) Det Norske Samlaget, Oslo, p 1230

Matsuda Y, Hijii N (2004) Ectomycorrhizal fungal communities in an Abies firma forest, with special reference to ectomycorrhizal associations between seedlings and mature trees. Can J Bot 82:822-829

Matsuda Y, Noguchi Y, Ito S (2009) Ectomycorrhizal fungal community of naturally regenerated Pinus thunbergii seedlings in a coastal pine forest. J For Res 14:335-341

Newton AC, Haigh J (1998) Diversity of ectomycorrhizal fungi in the UK: a test of the species-area relationship and the role of host preference. New Phytol 138:619-627

Nieto MP, Carbone SS (2009) Characterization of juvenile maritime pine (Pinus pinaster Ait.) ectomycorrhizal fungal community using morphotyping, direct sequencing and fruitbodies sampling. Mycorrhiza 19:91-98

Obase K, Cha JY, Lee JK, Lee SY, Lee JH, Chun KW (2009) Ectomycorrhizal fungal communities associated with Pinus thunbergii in the eastern coastal pine forests of Korea. Mycorrhiza 20:39-49

Øyen B-H (1999) Buskfuru og bergfuru - en historie fra kystskogbruket i Norge. Blyttia 57:162-170

Parlade J, Cohen M, Doltra J, Luque J, Pera J (2001) Continuous measurement of stem-diameter growth response of Pinus pinea seedlings mycorrhizal with Rhizopogon roseolus and submitted to two water regimes. Mycorrhiza 11:129-136

Peay KG, Bruns TD, Kennedy PG, Bergemann SE, Garbelotto M (2007) A strong species-area relationship for eukaryotic soil microbes: island size matters for ectomycorrhizal fungi. Ecol Lett 10:470-480

Peter M, Ayer F, Cudlín P, Egli S (2008) Belowground ectomycorrhizal communities in three Norway spruce stands with different degrees of decline in the Czech Republic. Mycorrhiza 18:157-169

Piękoś-Mirkowa H, Mirek Z (1996) Zespoły roślinne [Plant communities]. In: Mirek Z, Głowaciński Z, Klimek K, Piękoś-Mirkowa H (eds) Przyroda Tatrzańskiego Parku Narodowego [Nature of the Tatra National Park]. TPN, Cracow-Zakopane, pp 237-274, in Polish

Querejeta JI, Egerton-Warburton LM, Allen MF (2003) Direct nocturnal water transfer from oaks to their mycorrhizal symbionts during severe soil drying. Oecologia 134:55-64

Raidl S, Beenken L, Agerer R (1998) Rhizopogon melanogastroides M. Lange + Pinus mugo Turra. Descriptions of Ectomycorrhizae 3:99-104

Richardson DM (ed) (1998) Ecology and biogeography of Pinus. Cambridge University Press, Cambridge

Ronikier A (2009) Subalpine communities of dwarf mountain-pine: a habitat favourable for fungi. Nova Hedwig 89:49-70

Rudawska M, Leski T, Trocha LK, Gornowicz R (2006) Ectomycorrhizal status of Norway spruce seedlings from bare-root forest nurseries. For Ecol Manag 236:375-384

Scattolin L, Montecchio L, Mosca E, Agere R (2008) Vertical distribution of the ectomycorrhizal community in the top soil of Norway spruce stands. Eur J For Res 127:347-357

Shi LB, Guttenberger M, Kottke I, Hampp R (2002) The effect of drought on mycorrhizas of beech (Fagus sylvatica L.): changes in community structure, and the content of carbohydrates and nitrogen storage bodies of the fungi. Mycorrhiza 12:303-311

Smit E, Veenman C, Baar J (2003) Molecular analysis of ectomycorrhizal basidiomycete communities in a Pinus sylvestris L. stand reveals long-term increased diversity after removal of litter and humus layers. FEMS Microbiol Ecol 45:49-57

Smith SE, Read DJ (1997) Mycorrhizal symbiosis. Academic, London Strakauskaitė N (2004) Klaipeda and the Curonian Spit guide. Paknio, Klaipeda, ISBN 9986-830-87-7, p 80 
Taniguchi T, Kanzaki N, Tamai S, Yamanaka N, Futai K (2007) Does ectomycorrhizal fungal community structure vary along a Japanese black pine (Pinus thunbergii) to black locust (Robinia pseudoacacia) gradient. New Phytol 173:322334

Tedersoo L, Suvi T, Jairus T, Kõljalg U (2008) Forest microsite effects on community composition of ectomycorrhizal fungi on seedlings of Picea abies and Betula pendula. Environ Microbiol 10:1189-1201

Trappe JM (1962) Fungus associates of ectotrophic mycorrhizae. Bot Rev 28:538-606

Treu R (1990) Russula firmula. In: Agerer R (ed) Colour atlas of ectomycorrhizae. Einhorn, Schwäbisch Gmünd, pl. 43
Uhl M, Agerer R (1987) Studies on ectomycorrhizae XI. Mycorrhizae formed by Dermocybe crocea on Pinus sylvestris and Dermocybe palustris on Pinus mugo. Nova Hedwig 45:509-527

Walker JF, Miller OK Jr, Horton JL (2005) Hyperdiversity of ectomycorrhizal fungus assemblages on oak seedlings in mixed forests in the southern Appalachian Mountains. Mol Ecol 14:829-838

White TJ, Bruns T, Lee S, Taylor J (1990) Amplification and direct sequencing of fungal ribosomal RNA genes for phylogenetics. In: Innis MA, Gelfaud DH, Sninsky JJ, White TJ (eds) A guide to methods and applications. Academic, San Diego, pp 315-322

Wiemken V, Boller T (2006) Delayed succession from alpine grassland to savannah with upright pine: limitation by ectomycorrhiza formation? For Ecol Manag 23:492-502 